\title{
Chromosome mapping of five differently expressed miRNAs in porcine skeletal muscle development (Brief Report)
}

\author{
Kartierung von fünf miRNA mit differenzieller Expression während \\ der Skelettmuskelentwicklung beim Schwein (Brief Report)
}

\section{HUA BIN HE, SHU HONG ZHAO and XIN YUN LI}

Key Lab of Agricultural Animal Genetics, Breeding, and Reproduction of Ministry of Education \& Key Laboratory of Swine Genetics and Breeding of Ministry of Agriculture, Huazhong Agricultural University, Wuhan, Hubei, PR China

\section{Background}

MicroRNAs (miRNAs) are a class of short, non-coding regulatory RNAs, which are approximately 22 nucleotides in length. Typically, miRNAs negatively regulate gene expression by binding with the 3' untranslated region (UTR) of its regulatory target mRNAs. MicroRNAs are known to play diverse roles in fundamental biological processes, such as proliferation, differentiation and apoptosis (BARTEL 2004, 2009). It has been reported that miR-1, miR-133, miR-181 and miR-206 play important roles in skeletal muscle proliferation and hypertrophy (CALLIS et al. 2007, McCARTHY-ESSER 2007). We have detected porcine miRNA expression profiles during different stage of skeletal muscle development and a total of 140 miRNAs were differentially expressed (HUANG et al. 2008). In this study, we mapped five differentially expressed miRNAs (mir-29c, mir-103-1, mir-127, mir-193b and mir-218-1) using the radiation hybrid (IMpRH) panel (YERLE et al. 1998).

\section{Procedures}

Primer design

Pre-miRNA sequences of the five miRNAs of human were collected from miRBase (http:// microrna.sanger.ac.uk/sequences/) firstly. Then the porcine orthologues of human premiRNAs (identity $>90 \%$ ) were collected by comparing with all sequences available in the porcine Traces-other database using the BLAST algorithm (http://www.ncbi.nlm.nih.gov/ genome/seq/BlastGen/BlastGen.cgi?taxid=9823). The primers were designed according to the DNA sequence containing the porcine pre-miRNAs. The primer sequences are as follows:

miR-29c-F: 5'-AGC AGC CAC CAG CCG TAA G-3' miR-103-1-F: 5'-GGA TGT TCG GGT AGT TTG CAG-3' miR-127-F: 5'-CCA GCT TTG TGA ACC ACG TAG-3' miR-193b-F: 5'-GGG TGG CCT TTC CAG AAC-3' miR-218-1-F: 5'-CAG TTC TGA GGA ACG TTG GAG-3'
miR-29C-R: 5'-TGC CCA TCC ATC TTC CAG-3' miR-103-1-R: 5'-AGG TCA ATG CAG CAG AAC ATG-3' miR-127-R: 5'-GGA GGT CGA CTG GGT CAA AG-3' miR-193b-R: 5'-GAG GCT GAG CTG CTG AAT G-3' miR-218-1-R: 5'-GGC AAA TAG ATG GAC TCA GGT AG-3' 


\section{RH mapping}

The PCR was performed in a $10 \mu \mathrm{L}$ mixture containing $1 \times$ buffer, 20 ng panel DNA, $0.3 \mu \mathrm{M}$ each primer, $75 \mu \mathrm{M}$ dNTP, and $1.0 \mathrm{U}$ Taq DNA polymerase (TaKaRa, Dalian, P. R. C.). The PCR profile consisted of $4 \mathrm{~min}$ at $94^{\circ} \mathrm{C}, 35 \mathrm{cycles}$ of $30 \mathrm{~s}$ at $94^{\circ} \mathrm{C}, 30 \mathrm{~s}$ at $60 \sim 63^{\circ} \mathrm{C}, 30 \mathrm{~s}$ at $72^{\circ} \mathrm{C}$, and a final 5 min extension at $72^{\circ} \mathrm{C}$. The PCR results were submitted and analysed using the chromosome mapping tool available on INRA website http://imprh.toulouse.inra.fr/.

\section{Results}

The mapping results of all the five miRNA genes are presented in Table 1. According to the mapping results, all the porcine miRNA genes are significantly linked to markers in the $\mathrm{RH}$ mapping database. Moreover according to the comparative map, the porcine miRNA mapping positions are consistent with human miRNA locations (http://www.toulouse.inra.fr/ lgc/pig/compare/compare.htm) (GOUREAU et al. 1996).

Table 1

The mapping results of the miRNAs

Ergebnisse der Kartierung der miRNAs

\begin{tabular}{lcccccc}
\hline $\begin{array}{l}\text { Gene } \\
\text { Symbol }\end{array}$ & $\begin{array}{c}\text { Human } \\
\text { chromosome } \\
\text { mapping }\end{array}$ & $\begin{array}{c}\text { Closely linked } \\
\text { marker }\end{array}$ & $\begin{array}{c}\text { location of } \\
\text { the marker }\end{array}$ & $\begin{array}{c}\text { Distance } \\
\text { (CR) }\end{array}$ & $\begin{array}{c}\text { LOD } \\
\text { score }\end{array}$ & $\begin{array}{c}\text { Retention } \\
\text { fraction, \% }\end{array}$ \\
\hline miR-29c & $1 \mathrm{q} 32.2$ & SW1651 & $9 \mathrm{q} 2.6$ & 68 & 5.27 & 19 \\
miR-103-1 & $5 \mathrm{q} 35.1$ & SW977 & $16 \mathrm{q}$ & 53 & 7.4 & 37 \\
miR-127 & $14 \mathrm{q} 32.31$ & SSC12B09 & $7 \mathrm{q} 2.6$ & 15 & 15.89 & 24 \\
miR-193b & $16 \mathrm{p} 13.12$ & SW487 & $3 \mathrm{p}$ & 81 & 3.76 & 14 \\
miR-218-1 & 4p15.31 & SW268 & $8 \mathrm{p}$ & 24 & 12.93 & 23 \\
\hline
\end{tabular}

\section{Acknowledgements}

We thank Dr Martine Yerle for providing IMpRH panel. This research was supported by the National Natural Science Foundation (30901020) of China and the China National Fundamental Fund of Personnel Training (J0730649).

\section{References}

Bartel DP (2004) MicroRNAs: genomics, biogenesis, mechanism, and function. Cell 116, 281-97

Bartel DP (2009) MicroRNAs: target recognition and regulatory functions. Cell 136, 215-33

Callis TE, Chen JF, Wang DZ (2007) MicroRNAs in skeletal and cardiac muscle development. DNA Cell Biol 26, 219-25

Goureau A, Yerle M, Schmitz A, Riquet J, Milan D, Pinton P, Frelat G, Gellin J (1996) Human and porcine correspondence of chromosome segments using bidirectional chromosome painting. Genomics 36, 252-62

Huang TH, Zhu MJ, Li XY, Zhao SH (2008) Discovery of porcine microRNAs and profiling from skeletal muscle tissues during development. PLoS ONE 3, e3225

McCarthy JJ, Esser KA (2007) MicroRNA-1 and microRNA-133a expression are decreased during skeletal muscle hypertrophy. J Appl Physiol 102, 306-13 
Yerle M, Pinton P, Robic A, Alfonso A, Palvadeau Y, Delcros C, Hawken R, Alexander L, Beattie C, Schook L, Milan D, Gellin J (1998) Construction of a whole-genome radiation hybrid panel for high-resolution gene mapping in pigs. Cytogenet Cell Genet 82, 182-8

Received 3 June 2009, accepted 26 October 2010.

Corresponding author:

\section{XINYUN LI}

email: hzaulxy@163.com

Key Laboratory of Agricultural Animal Genetics, Breeding, and Reproduction of Ministry of Education \& Key Laboratory of Swine Genetics and Breeding of Ministry of Agriculture, Huazhong Agricultural University, Wuhan 430070, Hubei, PR China 